\title{
HUKUM CAGAR BUDAYA DAN KORESPONDENSINYA DENGAN PERLINDUNGAN BANGUNAN PENINGGALAN KOLONIAL BELANDA DI INDONESIA
}

Oleh :

\section{Noor Tri Hastuti}

\begin{abstract}
Normatively, the preventive regulation of nature and archeological preservation, including ancient Dutch/ Colonial buildings has been set, i.e. UU of environment and of lay out planning. It is intended to optimally avoid the destruction of Indonesian culture and 'profit oriented only' building constructions. It is also expected to increase the responsibility of the government officers as the person in charge in the preservation scheme of historical valuables.
\end{abstract}

Keywords : Preservation, responsibility, historical valuables,

\section{PENDAHULUAN}

Perlindungan hukum terhadap cagar budaya di Indonesia telah dijamin oleh Pasal 32 UUD 1945 dan penjelesannya yang menyatakan : "Pemerintah kebudayaan nasional Indonesia. Usaha kebudayaan harus menuju kearah kemajuan adab, dan persatuan dengan tidak menolak bahan-bahan dari kebudayaan asing yang dapat memperkembangkan atau memperkaya kebudayaan bangsa sendiri, serta mempertinggi derajat bangsa Indonesia".

Jaminan UUD 1945 tersebut, dioperasionalkan lebih lanjut dengan Ketetapan MPR Nomor II/MPR/1988 tentang GBHN yang mengamanatkan agar kebudayaan Indonesia yang mencerminkan nilai-nilai luhur bangsa, harus dipelihara, dibina dan dikembangkan guna memperkuat penghayatan dan pengamalan Pancasila, meningkatkan kualitas hidup, memperkuat kepribadian bangsa, mempertebal rasa harga diri dan kebangsaan nasional, memperkokoh jiwa persatuan dan kesatuan bangsa serta mampu menjadi penggerak bagi perwujudan cita-cita bangsa ke masa depan.

Atas dasar amanat GBHN di atas, maka dibentuk UUNo. 5 Tahun 1992 tentang Benda Cagar Budaya dan PP No. 10 Tahun 1993 sebagai aturan pelaksanaannya yang bertujuan untuk melindungi, melestarikan dan memanfaatkan benda-benda cagar budaya guna memajukan kebudayaan nasional Indo- 
nesia.

Dengan berlakunya perundang-undangan cagar budaya dimaksud maka Monumenten Ordonantie Nomor 19 Tahun 1931 (Stbl 1931 Nomor 238 sebagaimana telah diubah dengan monumenten Ordonantie Nomor 21 Tahun 1934 dinyatakan tidak berlaku.

Upaya melindungi dan melestarikan bendabenda cagar budaya tidak hanya didasarkan pada UU Nomor 5 Tahun 1992 dan PP No. 10 Tahun 1993, tetapi diperkuat juga oleh UU No. 23 Tahun 1997 tentang Pengelolaan Lingkungan Hidup jo UU No. 24 Tahun 1992 tentang Penataan Ruang. Tegasnya, Indonesia sebagai Negara Hukum dan bagian dari masyarakat internasional yang berbudaya telah memiliki instrumen yuridis yang kuat untuk menjaga, melindungi dan melestarikan benda-benda cagar budaya diseluruh wilayah nusantara.

Persoalannya seberapa jauh peraturan perundangundangan di atas telah difungsikan untuk melindungi dan melestarikan bangunan-bangunan bersejarah peninggalan zaman kolonial Belanda yang ada di wilayah nusantara?

\section{Tolok Ukur Arsitektural dan Ketentuan Normatifnya}

Maksud diterbitkannya Hukum Cagar Budaya untuk melindungi benda-benda kuno. Istilah Cagar Budaya sendiri berarti Perlindungan atau yang dilindungi oleh pemerintah agar tidak rusak terutama menyangkut benda-benda budaya. Batasan suatu benda peninggalan yang dinilai kuno bisa didasarkan atas tolok ukur arsitektural yang dapat dipakai pedoman secara teknis adalah sebagai berikut :

(Eko B. \& Sudarti HH : 1993 : h. 123.)

1. Gaya bangunan (style)

2. Keunikan Seni Kriya (works manship)

3. Lingkungan sekitar bangunan (setting)

4. Kekhasan bahan bangunan (materials)

5. Keluwesan (fleksibilitas)

6. Kegunaan(function)

7. Kesinambungan kemanfaatan (continuity)

8. Keaslian ekspresi

Tolok ukur ini memiliki manfaat yang besar untuk Revitalisasi Kawasan Kuno. Dari tolok ukur ini juga tampak bahwasannya, penghargaan pelestarian budaya ini tidak individual building tetapi meliputi : daerah perlindungan alam (Conservation Areas) ; daerah bersejarah (historic areas) ; kota bersejarah (historic tawns) serta hitoric landscape, yang kesemua area ini di sebut sebagai kawasan lindung. (pasal 1 angka 7 UU No. 24 Th. 1992).

Sedang dalam ketentuan hukum positifnya (normatifnya) Cagar Budaya dapat diuraikan dalam kategori sebagai berikut: (pasal 1 ayat (19) UUNo. 5 Th. 1992).

1. Benda buatan manusia

2. Bergerak/tidak bergerak yang berupa kesatuan/kelompok.

3. Yang berumur sekurang-kurangnya 50 
tahun.

4. Mewakili gaya khas dan mewakili masa gaya.

5. Memiliki nilai penting sejarah

6. Memiliki nilai penting bagi ilmu pengetahuan.

7. Memiliki nilai penting kebudayaan.

UU No. 5 Th. 1992 tentang Cagar Budaya, secara umum mengatur 3 aspek :

1. Aspek pengaturan; aspek ini mengatur beberapa kegiatan yang berkaitan dengan :

a. Penguasaan, diatur dalam pasal 4 dan 5 , bahwa negaralah yang menguasai bendabenda cagar budaya tersebut, baik yang berada di dalam wilayah hukum Republik Indonesia maupun yang berada di luar sifat, jumlah dan jenis dalam hal untuk kepentingan sejarah, ilmu pengetahuan dan kebudayaan yang perlu dilestarikan.

b. Pemilikan, diatur dalam pasal 6-9 benda cagar budaya dapat dimiliki oleh negara, badan hukum, yayasan, perhimpunan serta orang yang memiliki, menguasai secara turun temurun dengan tetap memperhatikan fungsi sosialnya.

c. Penemuan, diatur dalam pasal $10-11$.

Dalam hal ada penemuan benda cagar budaya, si penemu wajib melaporkan kepada pemerintah untuk segera dilakukan penelitian dan tindakan selanjutnya.

d. Pencarian, benda cagar budaya, di atur dalam pasal 12 secara prinsip kegiatan ini harus dilakukan dengan secara prinsip kegiatan ini harus dilakukan dengan seizin pemerintah.

e. Pengelolaan, benda cagar budaya diatur dalam pasal 18 pengelolaan adalah tanggungjawab pemerintah dan terbuka bagi adanya peran serta masyarakat kelompok atau perorangan.

f. Pemnafaatan, diatur dalam pasal 19-23, benda cagar budaya (tertentu) dapat dimanfaatkan untuk kepentingan agama, sosial, pariwisata, pendidikan, ilmu pengetahuan dan kebudayaan.

2. Aspek perlindungan hukum secara preventif (Phillipus M. Hadjon ; 1985 : 3 -4). Untuk benda-benda cagar budaya, meliputi adanya kegiatan melindungi dan memelihara wajibuntuk setiap orang. (pasal $13 ; 14 ; 17$ jo pasal $25 \mathrm{PP}$ No.10 Th. 1992). Termasuk juga kegiatan pengawasan, yang oleh undang-undang diotoritaskan kepada pemerintah dan dilakukan secara terpadu dengan berbagai instansi yang terkait.

3. Aspek perlindungan hukum secara Represif Dalam kekuatan normatifnya Undang-undang ini telah mengatur berbagai ketentuan sanksi, dalam hal :

a. Apabila merusak, memindahkan, mengambil, mengubah bentuk, warna, 
memugar tanpa izin, memisahkan serta memperjualbelikan, dekenai pidana penjara 10 tahun dan / atau denda 10 juta.

b. Dalam hal mencari benda-benda cagar budaya tanpa izin dikenakan pidana penjara selama-lamanya dan/atau denda 50 juta.

c. Dalam hal tidak mendaftar, tidak melapor, menghilangkan, merusak dan memanfaatkan kembali dikenai pidana 1 tahun dan/atau denda 10 juta.

\section{Realita Penegakan Hukum Cagar Budaya}

Benda-benda cagar budaya berupa gedunggedung pemerintah, perdagangan, istana pejabat negara, balai-balai kota, musium, Hotel, rumahrumah pribadi, benteng-benteng pertahanan, berikut benda-benda bersejarah lainnya, yang memiliki nilai arsitektur tinggi peninggalan pemerintah kolonial Belanda, tampaknya dari tahun ke tahun semakin berkurang. Bahkan majalah Detak No. 64 Tahun Ke-2, 12 - 18 Oktober 1999 dalam salah satu topiknya menyatakan : "Bangunan-bangunan tua dan bersejarah masih rawan dari ancaman penghancuran, peraturan yang ada belum mampu melindunginya".

Banyak contoh kasus dikemukakan oleh majalah Detak untuk mendukung kekhawatiran pemyataan di atas. Antara lain penggusuran bangunanbangunan tua pada tahun 1970-an pada saat pemekaran dan pembangunan kota dikawasan
Tunjungan, Kembang Jepun, Darmo (Surabaya), Kayutangan (Malang), Omah Setan, Gedung Kanjengan, Gedung Gulo, Stasiun Jurnatan (Semarang)< Biri-biri Gestich (Bogor), Hotel Des Indes, Hotel Der Nederlanden, societeit der Harmonie (Jakarta). Juga yang paling aktual, ialah hancurnya gedung Nederlands Indische Kunstkring (NIK) di jalan Teuku Umar No. 1 Jakarta Pusat berikut penjarahan terhadap semua benda-benda berharga yang ada di dalamnya.

Beberapa contoh kasus tersebut menggambarkan tidak konsistennya perilaku pemerintah di dalam melaksanakan pembangunan dan penegakan hukum. Di satu pihak, peraturan perundang-undangan cagar budaya, pengelolaan lingkungan hidup dan penataan ruang yang nota bene dibuat oleh pemerintah sendiri telah mengatur upaya perlindungan dan pelestarian gedung-gedung bersejarah, di lain pihak justru pemerintah sendiri yang melanggarnya. Realitas ini sungguh-sungguh ironis. Sebab jika pemerintah sudah tidak memperdulikan norma-norma hukum yang mengharuskan pemeliharaan, pelestarian dan pengembangan kebudayaan nasional, lalu siapa lagi yang dapat dipanuti oleh warga masyarakat untuk mempertahankan benda-benda cagar budaya ? Jadi di sini sesungguhnya bukan peraturan hukum yang tampaknya belum kuasa melindungi bendabenda cagar budaya, tetapi pemerintahlah yang tidak memiliki budaya hukum untuk 
melaksanakan dan mentaati peraturan hukum secara konsekuen dan konsisten (Satjipto Rahardjo, $1981 ; 167-168$ ).

Secara teoritis, ada empat faktor utama yang menentukan berfungsinya hukum secara efektif di dalam kehidupan masyarakat, berbangsa dan bernegara, yaitu: kelayakan peraturan perundangundangan, pelaku aparatur penegak hukum, sarana dan prasarana hukum, serta kesadaran hukum warga masyarakat. (Soejono Soekamto, $1983 ; 15)$.

Jika dicermati UU No. 5 Tahun 1992 dan PP No. 10 Tahun 1993 sesungguhnya sudah cukup layak aspek formal maupun materialnya dalam mengatur upaya perlindungan dan pelestarian cagar budaya. Pasal 1 ayat 1 huruf a UUNo. 5 Tahun 1992 dengan tegas menyatakan: "benda buatan manusia, bergerak atau tidak bergerak yang berupa kesatuan atau kelompok, atau bagian-bagiannya atau sisa-sisanya, yang berumur sekurangkurangnya 50 (lima puluh) tahun, atau mewakili masa gaya yang khas dan mewakili masa gaya 50 (lima puluh) tahun, serta dianggap mempunyai nilai penting bagi sejarah, ilmu pengetahuan, dan kebudayaan. Kemudian pasal 2 ayat (1) PP No. 10 Tahun 1993 menentukan : "Untuk perlindungan dan/atau pelestarian benda-benda cagar budaya, benda yang diduga benda cagar budaya, benda berharga yang tidak diketahui pemiliknya baik bergerak maupun tidak bergerak, dan situs yang berada di wilayah Republik Indonesia".

Ketentuan normatif pasal-pasal peraturan perundang-undangan cagar budaya di atas secara jelas mewajibkan pemerintah dan perangkatperangkatnya untuk pro aktif untuk menginventarisasi, menilai menetapkan, melindungi, dan melestarikan segala bentuk benda-benda cagar budaya yang nyata-nyata, diduga atau dianggap memiliki nilai sejarah sebagai benda cagar budaya. Tentunya termasuk juga gedung-gedung bersejarah peninggalan zaman kolonialis Belanda yang bernilai penting bagi pusat pengkajian sejarah, ilmu pengetahuan dan kebudayaan.

Kewajiban pihak pemerintah yang demikian itu, seharusnya diimplementasikan secara konkret dalam berbagai bentuk kebijakan penyelenggaraan pemerintahan dan pembangunan. Dalam penyelenggaraan pemerintahan dan pembangunan, seyogyanya Pemerintah Pusat dan Pemerintah Daerah melalui BAPPENAS, BAPPEDA, DINAS-DINAS TATA KOTA, DINAS-DINAS PARIWISATA, DAN DINAS-DINAS KEBUDAYAAN memiliki Sumber Daya Manusia yang ahli dibidang : arsitektur, sejarah, arkeologi, sosial budaya, dan sebagainya yang mampu menghayati, menilai dan memperjuangkan upaya-upaya melestarikan bendabenda cagar budaya. Sayangnya sampai kini justru sumber daya manusia seperti itulah yang masih langka 
dibumi Indonesia. Bahkan selama era pemerintahan orde baru yang serba pragmatis, materialistis dan berorientasi ekonomi, sehingga sebagian besar manusia Indonesia agaknya tidak begitu tertarik untuk berprofesi sebagai tenaga pelestari benda-benda cagar budaya. Sebaliknya yang banyak mengedepan hanyalah manusia-manusia pemburu benda-benda cagar budaya dengan maksud memperdagangkan dan mencari keuntungan pribadi yang sebesarbesarnya. Maka tidak mengherankan, jika kerapkali terjadi pencarian, pencurian dan perusakan terhadap benda-benda cagar budaya yang pada hakikatnya merupakan tindakan bunuh diri(suicide) bagi kebudayaan nasional.

\section{Hambatan Penegakan Hukum Cagar Budaya}

Selain itu, tak kalah pentingnya faktor sumber daya keuangan yang seharusnya disediakan guna menyelenggarakan urusan-urusan yang langsung maupun tidak langsung berkaitan dengan upaya melindungi, memelihara dan melestarikan bendabenda cagar budaya-termasuk gedung-gedung bersejarah peninggalan zaman kolonialis Belanda. Dapat dikatakan anggaran yang disediakan untuk itu selama pemerintahan orde baru sangat tidak sebanding dengan anggaran-anggaran yang diperioritaskan pada sasaran-sasaran pembangunan fisik yang lebih berniali ekonomis. (Satjipto R.ahardjo, 143 - 147). Konsekuensinya kerapkali terdengar keluhan-keluhan tentang keterbatasan dana untuk melaksanakan perundang-undangan cagar budaya secara optimal.

Demikian pula, kepedulian aparatur penegak hukum ketika menegakkan perundang-undangan cagar budaya. Seringkali terjadi kasus-kasus pencurian dan perusakan terhadap benda-benda cagar budaya, tetapi tidak diselesaikan secara tuntas. Ini tampaknya terkait dengan aspek moral penegak hukum dalam Negara Hukum Indonesia yang secara menyeluruh ditengarai sangat lemah. Berbagai kasus besar seperti korupsi dan penyalahgunaan wewenang oleh pejabat-pejabat pemerintahan tidak diselesaikan secara tuntas, apalagi kasus-kasus yang menyangkut pencurian, penyelundupan dan perusakan terhadap benda-benda cagar budaya. Di sini faktor ketersediaan sarana dan prasarana penegakan hukum juga ikut menentukan. Tanpa didukung oleh sarana dan prasarana yang memadai maka penegakan hukum tidak akan berdayaguna dan berhasil guna.

Terakhir faktor kesadaran hukum warga masyarakat, secara umum merupakan faktor yang amat mendasar bagi tegaknya hukum. Setiap warga negara selalu diharapkan memiliki pemahaman, kesadaran dan budaya hukum yang baik. Namun menurut praktiknya tetap masih jauh dari harapan. Demikian juga yang terjadi di bidang perlindungan dan pelestarian benda-benda cagar budaya

\section{Upaya Penegakan Hukum Cagar Budaya}

Oleh karena itu, dalam upaya menegakkan 
peraturan hukum cagar budaya dan korespondensinya dengan upaya melindungi bangunan-bangunan bersejarah peninggalan zaman kolonialis Belanda, perlu dilakukan langkah-langkah sebagai berikut :

1. Meningkatkan kepedulian instansi pemerintah di tingkat pusat maupun daerah untuk melaksanakan dengan sungguhsungguh UU No. 5 Tahun 1992, PP No. 10 Tahun 1993 dan peraturan perundangundangan yang berkaitan dengan upaya pelestarian cagar budaya nasional. Kepedulian tersebut harus diwujudkan secara nyata dengan menginventarisir, menilai dan menetapkan bangunanbangunan bersejarah peninggalan kolonialis Belanda yang patut untuk dilestarikan.

2. Meningkatkan anggaran pemerintah dan atau partisipasi masyarakat untuk membiayai pemeliharaan gedung-gedung yang ditetapkan sebagai cagar budaya.

3. Meningkatkan kepedulian para ilmuwan, komponen-komponen mahasiswa, LSM, dan organisasi kemasyarakatan lainnya dalam upaya melestarikan benda-benda cagar budaya.

4. Melakukan kontrol sosial yang terus menerus dan efektif kepada pemerintah.

5. Menata sistem perizinan bangunan yang ketat di wilayah perkotaan agar dengan cermat mempertimbangkan penggusuran- penggusuran bangunan-bangunan yang memiliki nilai sejarah, ilmu pengetahuan dan kebudayaan.

6. Memproses sampai tuntas para pelaku yang melanggar ketentuan hukum cagar budaya dan menerapkan sanksi hukum secara maksimal.

Demikianlah paparan makalah singkat ini disampaikan, untuk dikembangkan lebih lanjut dalam Seminar/Talk show "Reorientasi Teknologi Peninggalan Zaman Belanda Dalam Pengembangan Teknologi Modern Di Indonesia".

\section{PENUTUP}

Negara Indonesia yang "Mengklaim" sebagai bangsa yang berbudaya, pengaturan secara normatif terhadap benda-benda kuno (peninggalan kolonial Belanda) atau benda-benda Cagar Budaya, merupakan langkah positif, bagi jaman dan perlindungan terhadap budaya nasional. Langkah yang lebih konkret harus diwujudkan dalam bentuk menetapkan dalam bentuk undang-undang bangunanbangunan bersejarah dan yang dilindungi.

Meningkatkan anggaran dan kepedulian pemerintah dan/atau partisipasi masyarakat merupakan terapi yang wajib untuk menghindari adanya bunuh diri kebudayaan. Di samping itu, diciptakan sarana kontrol sosial yang terus menerus 
dan efektif kepada pemerintah. Untuk penegakan hukumnya, pemerintah harus bersikap tegas kepada para pelaku pelanggar ketentuan hukum cagar budaya dengan penerapan sanksi yang semaksimal mungkin.

\section{DAFTAR PUSTAKA}

Djauhari Summintardjo, Kompendium Sejarah Arsitektur, Yayasan Penyelidikan Masalah Bangunan, Bandung, 1981.

Eko Budiharjo dan Sudanti Hardjo Huboyo, Kota Berwawasan Lingkungan, Alumni Bandung,, 1993.

Pillipus M. Hadjon, Perlindungan Hukum Bagi Rakyat, Bina Ilmu, Surabaya, 1983

Satjipto Rahardjo., Hukum dan Masyarakat, Angkasa, Bandung, 1980.

Bandung, 1986.

Soerjono Soekamto, Penegakan Hukum, Bina Cipta, Jakarta, 1983,

Detak, No. 64. Tahun ke-2, 12 - 18 Oktober 1999.

UU No. 5 Tahun. 1992 Tentang Benda Cagar Budaya, Alumni, Bandung, 1993.

PP No. 10 Tahun 1993, Pelaksanaan Benda Cagar Alam.

UU No. 23 Tahun 1997 Tentang Pengelolaan Lingkungan Hidup.

UUNo. 24 Tahun. 1992 Tentang Penataan Ruang. 